\title{
Deep-rooted "thick skinned" model for the High Atlas Mountains (Morocco). Implications for the seismic Eurasia-Africa plate boundary region
}

\author{
Modelo de cabalgamiento profundo para el Alto Atlas (Marruecos). \\ Implicaciones sísmicas en la zona de colisión entre Eurasia y Africa
}

\author{
A. G. El Harfi' ${ }^{1}$ M. Guiraud² ${ }^{2}$, J. Lang², E. H. Chellai ${ }^{3}$, N. Lachkar²
}

\begin{abstract}
Previous crustal models of the High Atlas suppose the existence of a mid-crustal detachment where all the surface thrusts merged and below which the lower crust was continuous. However, both seismic refraction data and gravity modeling detected a jump in crustal thickness between the High Atlas and the northern plains. Here we show that this rapid and vertical jump in the depth of Moho discontinuity suggests that a thrust fault may penetrate the lower crust and offset the Moho (deep-rooted "thick skinned" model). The distribution of Neogene and Quaternary volcanisms along and at the northern part of the High Atlas lineament can be related to the beginning of a partial continental subduction of the West African plate to the north underneath Moroccan microplate. Allowing from the complex problem of the plate boundary in the western zone of the Mediterranean, we propose to interpret the South-Atlasic fault zone as the actual northwestern boundary of the stable part of the African plate rather than the Azores-Gibraltar fault currently used.
\end{abstract}

Key words: High Atlas, Moho, thick skinned model, subduction, Mediterranean plate tectonics, geophysical data.

\section{RESUMEN}

Los modelos geodinámicos existentes sobre la estructura profunda del alto Atlas suponen la existencia de un despegue medio-cortical donde convergen los cabalgamientos superficiales y bajo el cual la corteza inferior es continua. Los datos de sísmica de refracción y gravimetría, sin embargo, indican la existencia de una discontinuidad en el grosor de la corteza (profundidad del Moho) bajo el Alto Atlas.

En este artículo ponemos de manifiesto que este salto rápido en la profundidad del Moho puede ser causado por un cabalgamiento que penetra la corteza inferior, desplazando la base de la misma ("deeprooted thick skinned model").

La distribución del volcanismo Neógeno y Cuaternario a lo largo de y al norte de la alineación del Alto Atlas pueden estar relacionados con el comienzo de una subducción continental parcial de la placa Africana occidental hacia el norte, bajo la microplaca marroquí. La expresión en superficie de este cabalgamiento, la zona de falla sud-atlásica, refleja la influencia de una sutura continental heredada de orogenias anteriores (panafricana, hercínica y rifting Jurásico). Por tanto, proponemos que este frente heredado representa el límite meridional de la zona de colisión mediterránea y el margen noroccidental de la porción estable de la placa africana.

Palabras clave: Alto Atlas (Marruecos), Moho, modelo "thick skinned", subducción, Tectónica de placa mediterránea, datos geofísicos.

\section{Introduction}

The Atlas Mountains of North Africa (known as the High and Middle Atlas in Morocco, the Saharan
Atlas in Algeria and Tunisian Atlas in Tunisia) are considered as an intracontinental range and stretch unbroken for 2,000 km from the Atlantic in the West to Tunisia in the East (fig. 1). This is the largest

\footnotetext{
1 LAGAGE, Earth Science Center, Faculty of Science, University Ibn Zohr, BP 8106 Agadir, Morroco.

2 Earth Science Center, UMR 5561, University of Burgundy, 21000 Dijon, France.

3 Faculty of Science Semlalia, University Cadi Ayyad, BP S/15 Marrakech, Morroco. E-mail: elharfia@yahoo.fr.
} 


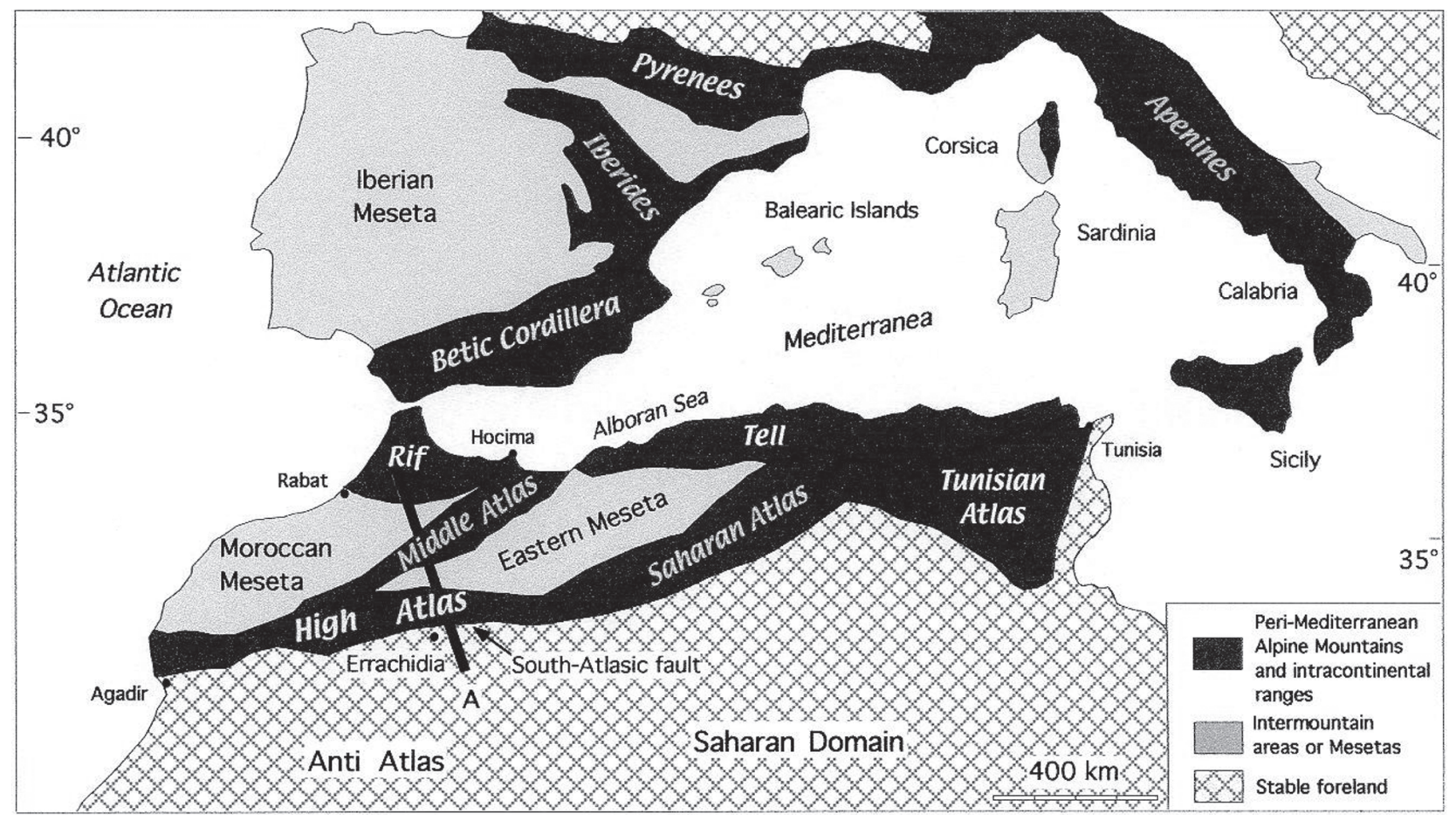

Fig. 1.-Sketch map of the western Mediterranean region showing the Atlas Range and the peri-Mediterranean alpine belt. A: cross sections of figures 2,3 and 4 .

Phanerozoic mountain range in Africa and it is similar in size and extent to the Appalachians and the Urals (Beauchamp et al., 1999).

Four mountain ranges form the Atlas system of Morocco (fig. 1): - The Rif chain in the North faces the Mediterranean Sea; - The Anti Atlas, the southernmost Atlas chain, is a marginal updoming of the Precambrian West Africa craton which acted as stable crust during Alpine orogeny; - The Middle and High Atlas (Atlas belt) are developed from Mesozoic rift grabens. These rifts are reversed in Cenozoic times to form the present-day Atlas Range, which rises to $4,165 \mathrm{~m}$, one of the highest peaks in the peri-Mediterranean Alpine system. These mountain belts are separated by two rigid and stable Palaeozoic blocks named: the Moroccan Meseta and the Eastern Meseta.

The Atlas Mountains (Middle and High Atlas) of Morocco is considered as an intracontinental range (Mattauer et al., 1977; Laville, 1985; Giese and Jacobshagen, 1992; Beauchamp et al., 1999; Piqué et al., 2002) located in the foreland of the Mediterranean Alpine belt (Betic Cordillera, Rif, Tell, e.g., fig. 1).

The High Atlas is separated from the West African craton (Anti Atlas) by a clear physiographic boundary often referred to as the "South-Atlasic fault"
("SAF", Russo and Russo, 1934). It was generally accepted that this fault (or a system of faults) is an important geosuture zone, which extends for about $1,900 \mathrm{~km}$ from Morocco to Tunisia. Weijermars (1987) even proposed a prolongation to the Adana region in southeastern Turkey. Unfortunately, at present, we have no subsurface data on the prolongation of this "SAF" farther north. Do the flat-lying faults which constitute the overthrust continue far towards the north, under the Atlas, as suggested by Giese and Jacobshagen (1992), or are they actually rooted in a steeply dipping fault system which represents the edge of the pre-existing Mesozoic trough? (El Harfi, 2001; Chorowicz et al., 2001; Piqué et al., 2002).

The Atlas belt is a tectonically complex area and is a part of the Eurasia-Africa plate boundary region. The deformation of the overall region is dominated by the converging and colliding African and Eurasian continents. Since the 1970s many tectonic and geodynamic models have been proposed to account for the origin and the specific structure of the intracontinental Atlas Range. However, there seems to be little literature about the deep structural make-up of the Moroccan Atlas.

Better knowledge of the crustal structure in the Atlas system of Morocco is important to better 


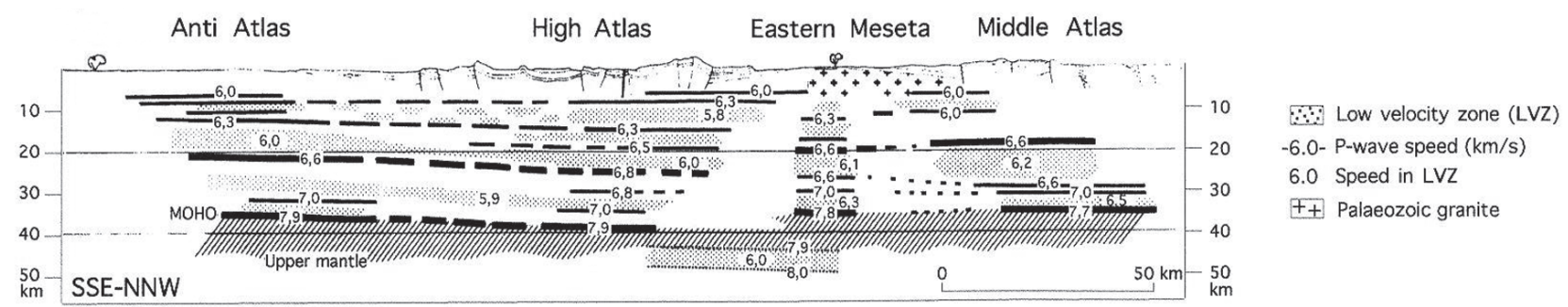

Fig. 2.-SSE-NNW crustal section of the High and Middle Atlas Mountains. The seismic refraction profiles along this section shows that the whole crust is strongly structured by alternating high and low seismic velocity zones (LVZ). Maximum crustal thickness (42 km) is found under the northern border of the High Atlas. The LVZs in the upper crust under the High Atlas dip slightly to the North, but a continuous transition to the NNW is not proven by the data. Note the presence of the subcrustal velocity inversion at $45-50 \mathrm{~km}$ depth between the lower crust and the upper mantle above the High/Middle Atlas (after Wigger et al., 1992; e.g., fig. 1 for section location).

understand the past and present tectonic and geodynamic evolution in the Eurasia-Africa plate boundary region. A detailed crustal model will also improve the origin and the accuracy of locating local and regional earthquakes that might put Mediterranean people at risk. In this paper we'll briefly expose and discuss the results of the seismological and electromagnetic data of the deep structure of the Atlas Mountain Range. Through a synthesis of recent structural and sedimentological results, we'll present a comprehensive geotectonical model that crosses the High Atlas belt, and we'll discuss the immediate far-reaching implications.

\section{Compilation of geophysical data along a traverse crossing the High and Middle Atlas Mountains of Morocco}

\section{Seismic refraction studies}

A compilation of the seismic refraction profiles along a NNW-SSE section (Wigger et al., 1992; figs. 1 and 2) demonstrates that there exists a lateral variation in the distribution of the LVZs (Low Seismic Velocity Zones), and the maximum is beneath the northern part of the High Atlas, in the area of maximal crustal thickness. The LVZs in the upper crust under the High Atlas dip slightly to the North, but a continuous transition to the NNW is not proven by the data. Moreover, the observed seismic data cannot prove how far the LVZ's sequences continue to the North beneath the Middle Atlas. Other major observation is the presence of the subcrustal velocity inversion and the LVZ at $45-50 \mathrm{~km}$ depth between the lower crust and the upper mantle above the High/Middle Atlas (fig. 2). This is supported by the relative low Pn velocity of 7.7-7.9 km/s.
Additional information has been recently obtained by receiver function studies of Sandvol et al. (1998) and Van der Meijde et al. (2003). The results of Van der Meijde et al. (2003) show that the Mohorovicic (Moho) discontinuity under Midelt (in the plains north of the High Atlas) is located at 39 $\mathrm{km}$. Sandvol et al. (1998) found, in fact two velocity jumps, at 36 and $39 \mathrm{~km}$; the shallowest one was interpreted by them as the crust-mantle boundary, whereas the deepest one remained uninterpreted.

\section{Moho depth and crustal thickness}

The recent result of the international MIDSEA (Mantle Investigation of the Deep Suture between Eurasia and Africa) project is the elaboration of a new map for the Moho discontinuity in the Eurasia-Africa plate boundary region (Marone et al., 2003). The reliable results, obtained for the northern African coasts, show that the western part of the African continent is characterized by a rapid change from a relatively deep Moho (down to $42 \mathrm{~km}$ ) below the Atlas Mountain Range to the thin crust $(<20 \mathrm{~km})$ of the southwestern Mediterranean Sea. According to detailed Seismic refraction studies of Wigger et al. (1992), the crustal thickness beneath the High Atlas is about $35-40 \mathrm{~km}$, being about $30-35 \mathrm{~km}$ in the peripheral plains (fig. 2). In comparison, deep seismic data for the Rif show that the Moho lies at a depth of 30-32 km in its central part and 20-25 km north of the Rif in the Alboran Sea (Michard et al., 2002).

\section{Gravity data and isostatic state}

Gravity and magnetic data displayed together with digital topographic data were provided by Makris et al. (1985); Tadili et al. (1986) and Beauchamp et al. 

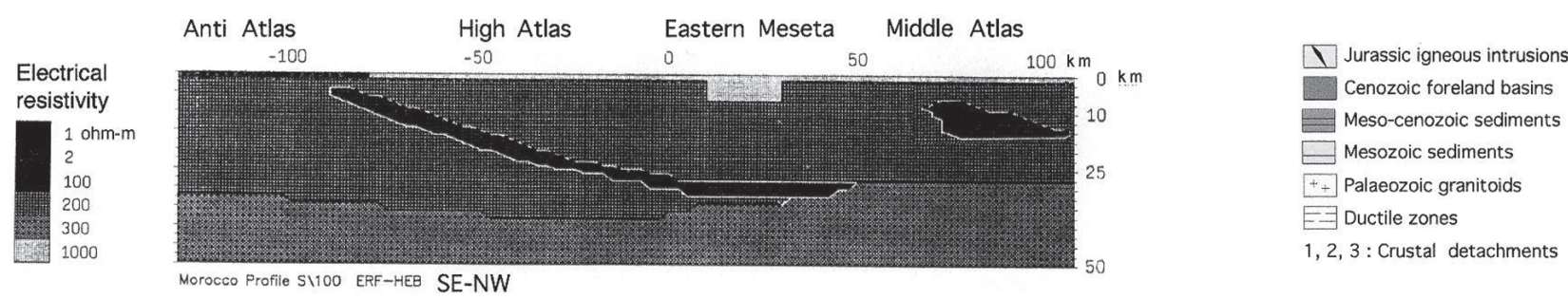

Fig. 3.-SE-NW electrical resistivity model across the High Atlas. Electrical resistivity of the middle and lower crust beneath the Anti Atlas was determined to about $200 \mathrm{ohm} \mathrm{m}$, the same as for the lower crust of the High and Middle Atlas. The model has a highly resistive (1000 ohm $\mathrm{m}$ ) uppermost mantle. This Model (S100) shows a rather steeply dipping high conductivity zone (HCZ), stretching from the southern border of the High Atlas almost down to Moho depth $(36 \mathrm{~km})$ beneath the Eastern Meseta and Middle Atlas (after Schwarz et al., 1992; e.g., fig. 1 for section location).

(1999). Remarkable results of these investigations are the asymmetry of the High Atlas Mountains and the fairly homogeneous crustal thickness, without large crustal roots in spite of the high topography. As summits may exceed 4,000 $\mathrm{m}$ in the High Atlas and 3,000 $\mathrm{m}$ in the Middle Atlas, several authors have proposed that the Atlas Mountains are in an uncompensated isostatic state (Makris et al., 1985; Gómez et al., 2000). Recently, Seismic wide angle and receiver function results, obtained by Ayarza et al. (2005), have been used as constraints to build a gravity-based crustal model of the central High Atlas of Morocco. Ayarza et al. (2005) concluded that gravity modelling suggests moderate crustal thickening and a general state of Airy isostatic undercompensation.

\section{Magnetotelluric investigations}

The electrical resistivity structure of the crust and upper mantle of the Atlas Mountain System was studied by Schwarz et al. (1992) using magnetotelluric and geomagnetic deep soundings. The final electrical model (2D S100) obtained by Schwarz et al. (1992) shows a crustal low resistivity layer with total conductance (thickness-resistivity ratio) of about 2,000 Siemens which stretches from the southern border of the High Atlas towards the Middle Atlas (fig. 3). In this model, the highly conductive zone (HCZ) dips steeply northwards plunging deep into the upper mantle beneath the Eastern Meseta. This model suggests that there is a deep fault (or fault system) that may extend down to the upper mantle.

\section{Proposal of a new geodynamical model}

Previous crustal models of the High Atlas suppose the existence of a mid-crustal detachment where all the surface thrusts merged and below which the lower crust was continuous (Giese and Jacobshagen, 1992). However, several questions are left unanswered by these previous models. furthermore, what explanation is there for?:

- The occurrence of a ramp of upper mantle (a jump in crustal thickness, figs. 2 and 3 ) beneath the northern border of the High Atlas. This ramp is shown up both by electrical resistivity modelling (Schwarz et al., 1992), seismic refraction data (Wigger et al., 1992) and gravity modeling (Makris et al., 1985).

- The origin of the subcrustal velocity inversion (LVZ), observed at 45-50 km depth, between the lower crust and the upper mantle above the High/Middle Atlas (fig. 2).

- The origin of the two receiver-function velocity jumps of Sandvol et al. (1998) and Van der Meijde et al. (2003). Their results show that the Moho discontinuity under Midelt is located at 36 and $39 \mathrm{~km}$.

- The occurrence of a significant gravimetric anomaly (values of less than $-150 \mathrm{mgal}$ ) for the southern slopes of the central and eastern High Atlas (Van den Bosch, 1971; Qureshi, 1986; Afrique 2002).

- The continuity of the LVZ layer at a depth of 10-20 km interpreted by Giese and Jacobshagen (1992) as horizontal detachment horizon. The observed seismic refraction data (fig. 2) cannot prove how far the LVZ layer in the upper crust under the High Atlas continues to the North beneath the Middle Atlas. Indeed, no continuous transition to the NNW is proven by the data.

These questions can be understood and solved with the adoption of the electrical model (HCZ, 2D S100) as geophysical solution for the interpretation of the deep structure of the High Atlas. Most probably, there is a clear correlation between 


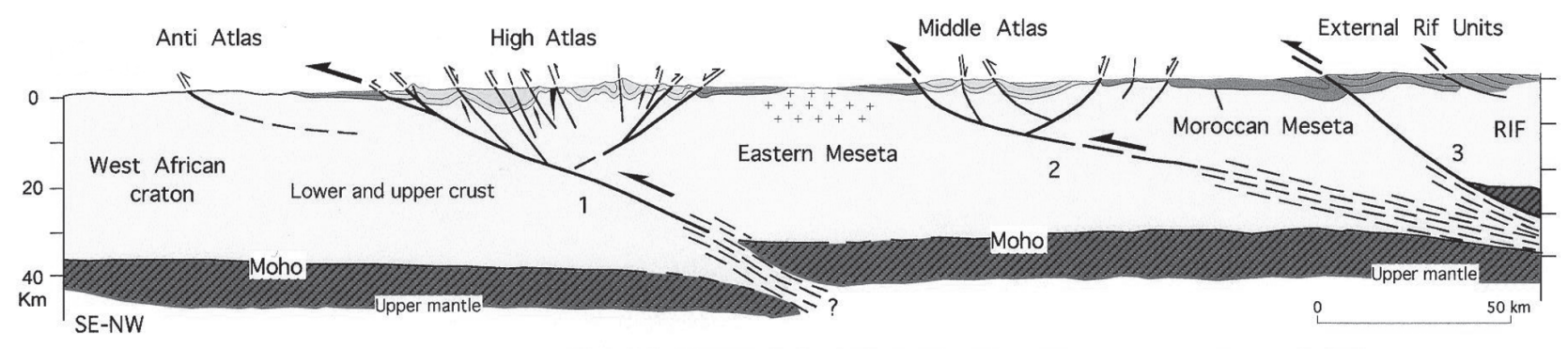

STABLE AFRICAN PLATE

MOBILE AND DIFFUSE SEISMIC ZONE BETWEEN AFRICAN AND EUROPEAN PLATES

Fig. 4.-SE-NW Conceptual crustal section through the major intracratonic ranges of the Atlas System of Morocco: High Atlas, Middle Atlas and Rif (modified and adapted from Giese and Jacobshagen, 1992; e.g., fig. 1 for section location). The comprehensive crustal section of the High Atlas is based on available geological data and a reinterpretation of geophysical data (El Harfi, 2001). The transect is supplemented by data collected by: Bernini et al. (2000) for the Middle Atlas, Seber et al. (1996) and Michard et al. (2002) for the Rif and MIDSEA (Mantle Investigation of the Deep Suture between Eurasia and Africa) Project (Marone et al., 2003) from the map of the Moho discontinuity.

the high conductive structure (HCZ), the jump in crustal thickness, revealed by seismic refraction data, and the southernmost boundary zone of the High Atlas chain ("SAF"). This crustal-scale thrust fault, whose existence was recently suggested by Ayarza et al. (2005) on the basis of gravity modelling, is also compatible with electrical resistivity modelling of Schwarz et al. (1992), and seismic refraction data of Wigger et al. (1992). In this solution, the conductive layer ( $\mathrm{HCZ}$ ), that can be interpreted as a zone of intense deformation with high fluid pressure, reaches Moho depths beneath the eastern Meseta.

These results provide a system which supports large crustal overthrusting events that has involved the whole crust under pure compression or transpressive deformation. This interpretation involves that the lower crust of the west African plate being overthrust (subduction) by the Moroccan and eastern Mesetas microplates, implying a crustal imbrication or a Moho duplication beneath the High Atlas.

The geometry of the large crustal faults and their extension at depth points to the occurrence beneath the northern border of the High Atlas of a deep lithospheric detachment, which roots in the lower crust and the upper mantle (fig. 4).

This is consistent with recent studies of Zeyen et al. (2005) and gravity data of Ayarza et al. (2005) which suggest that localized thickening appears restricted to the vicinity of a north-dipping crustalscale thrust fault, that offsets the Moho discontinuity and defines a small crustal root which accounts for the minimum Bouger gravity anomaly values. Gravity modelling of Ayarza et al. (2005) indicates that this root has a northeasterly strike, slightly oblique to the ENE general orientation of the High Atlas belt.

This result is also consistent with studies which anticipate that the tectonic of the High Atlas may be at least partly due to the inversion of steeply deep and inherited extensional fault from the Jurassic rifting (Piqué et al., 1987; Piqué and Michard, 1989; Laville and Piqué, 1991; Piqué et al., 1998).

It was generally accepted that the "SAF" is an important geosuture zone originated in pre-Permian times, because Permian and Triassic basins extended only to the north of that line. Recently, Ennih and Liégeois (2001) concluded that, during the PanAfrican orogeny, the northern limit of the West African craton was located at the "SAF". Indeed, only regions located to the north of this fault have been strongly affected by Phanerozoic orogenies. This fault zone coincides, furthermore, with the southern margins of Jurassic marine troughs (Rod, 1962; Piqué and Michard, 1989; Gomez et al., 2000). In the High Atlas, the inherited zone of crustal weakness ("SAF") is sufficiently weak to create separate crustal blocks within the diffuse plate boundary (Gomez et al., 2000; El Harfi, 2001; El Harfi et al., 2006). Dewey et al. (1973) assumed that this fault was a dextral transcurrent fault which separated a Mediterranean microplate from Africa in Mesozoic times. Indeed, Weijermars (1987) included this fault into the plate tectonic concept for the Mediterranean region and connected it with the Hayes transform fault of the Atlantic Ocean.

In the Atlas range, which is a domain of moderate shortening, crustal thickness along the central High Atlas profiles cannot entirely explain the observed topography and therefore, these mountains 
are not isostatically compensated. It follows that isostatic compensation has not been reached, and that there must be some additional mechanism to support the High Atlas elevation that is unrelated to shortening and crustal thickening (Beauchamp et al., 1999; El Harfi, 2001; Ayarza et al., 2005). An explanation for this fact lies on topography being partly supported by a thin, hot and less dense lithosphere (Seber et al., 1996). Strong lines of evidence are the existence of abundant alkaline volcanism in the Atlasic domain and the low P-wave velocities detected by Wigger et al. (1988) under the High Atlas. They suggest that the asthenosphere may occupy an anomalously high position helping to support the topography (Seber et al., 1996; Zeyen et al., 2005).

Finally, the occurrence of the subcrustal velocity inversion (LVZ), observed at 45-50 km depth, between the lower crust and the upper mantle, coupled with the distribution of Neogene and Quaternary volcanisms along and at the northern part of the High Atlas lineament, could be seen as a result of the beginning of a partial continental subduction of the West African plate under the Moroccan microplate (El Harfi 2001; Chorowicz et al., 2001). In the same case of the High Atlas Mountains, the two receiver-function velocity jumps at 36 and 39 $\mathrm{km}$ of Sandvol et al. (1998), has been interpreted as a Moho duplication by Ayarza et al. (2005). Such geodynamical mechanism is also detected in lithospheric structure of other small Alpine orogenic belts (e.g., the Pyrenees; Souriau and Granet, 1995; Roure and Choukroune, 1998; Beaumont et al., 2000; Vergés et al., 2002).

In addition, Tertiary and Quaternary alkaline volcanism (Harmand and Cantagrel, 1984; Berrahma and Delaloye, 1989; Ibhi, 2000), has been identified in the Middle Atlas, the Moroccan Meseta, the eastern Meseta, the northern part of the High Atlas, and in the Anti Atlas. The tectonic context in which this volcanism appears is not fully understood yet and was explained by Harmand and Moukadiri (1986) as the result of upper mantle deformation which permitted partial melting in a compressive regime.

This interpretation is also supported by Hatzfeld and Frogneux (1981), Medina and Cherkaoui (1991), who describe the depth range of 30-55 km beneath the High/Middle Atlas contact area as a seismic gap continued by an active seismic zone down beyond $60 \mathrm{~km}$. Although, the authors cannot exclude the possibility that deep seismicity in this region represents the remains of subducting crust.

\section{The Atlas belt in the Mediterranean Collision Zone (MCZ)}

Cenozoic plate motions across the Mediterranean region have previously been determined using Atlantic Ocean magnetic anomalies and closing the Africa-North America-Eurasia plate circuit (Dewey et al., 1989). Plate motions in this region have been accommodated over a broad zone comprising the Atlas Mountains as well as the Alpine chains along the Mediterranean coast. The recent work on the timing, kinematics of the positive inversion and magnitude of shortening (Beauchamp et al., 1999; Gomez et al., 2000; El Harfi, 2001; El Harfi et al., 2001) suggest that the High Atlas belt accommodated a significant fraction (17\%-45\%) of the plate convergence between Europe and Africa from the beginning of Eocene times.

The comparison of the deformed and restored sections of the High and Middle Atlas (Beauchamp et al., 1996, 1999) yields an Alpine shortening of some $36 \mathrm{~km}$ for this transect of the African plate, distributed in $31 \mathrm{~km}$ for the High Atlas and $5 \mathrm{~km}$ for the Middle Atlas, the latter being a value comparable to that previously obtained by Gomez et al. (1998). As demonstrated by the balanced cross section of Beauchamp et al. (1999), overthrusting at the margins of the central High Atlas nearly triples the magnitude of horizontal shortening across the $105 \mathrm{~km}$ wide mountain belt from $10 \%$ to $25 \%$. Overthrusting is significant because it permits the High Atlas range to accomodate considerably more horizontal shortening, involving steep faults. The thrust system of the High Atlas, which accommodates most of the shortening, is interpreted to penetrate into the deep crust and offset the Moho discontinuity, with a predominantly southern vergence. If the High Atlas Mountains has accommodated such a large fraction of the total plate convergence, then it should more properly be regarded as a significant element of the wide plate-boundary zone in the western Mediterranean.

It has previously been recognised that stable forelands in Africa and Europe are separated by a broad intensively Alpine deformed zone, referred to here as the Mediterranean Collision Zone (MCZ, fig. 5; Dewey et al., 1973; Weijermars, 1987; Gomez et al., 2000). This later involves several stable and rigid microplates (Moroccan Meseta, Eastern Meseta, Iberian Meseta, Alboran block...) which can be interpreted in a fashion similar to the impingement of the Indian plate with Tibet before 


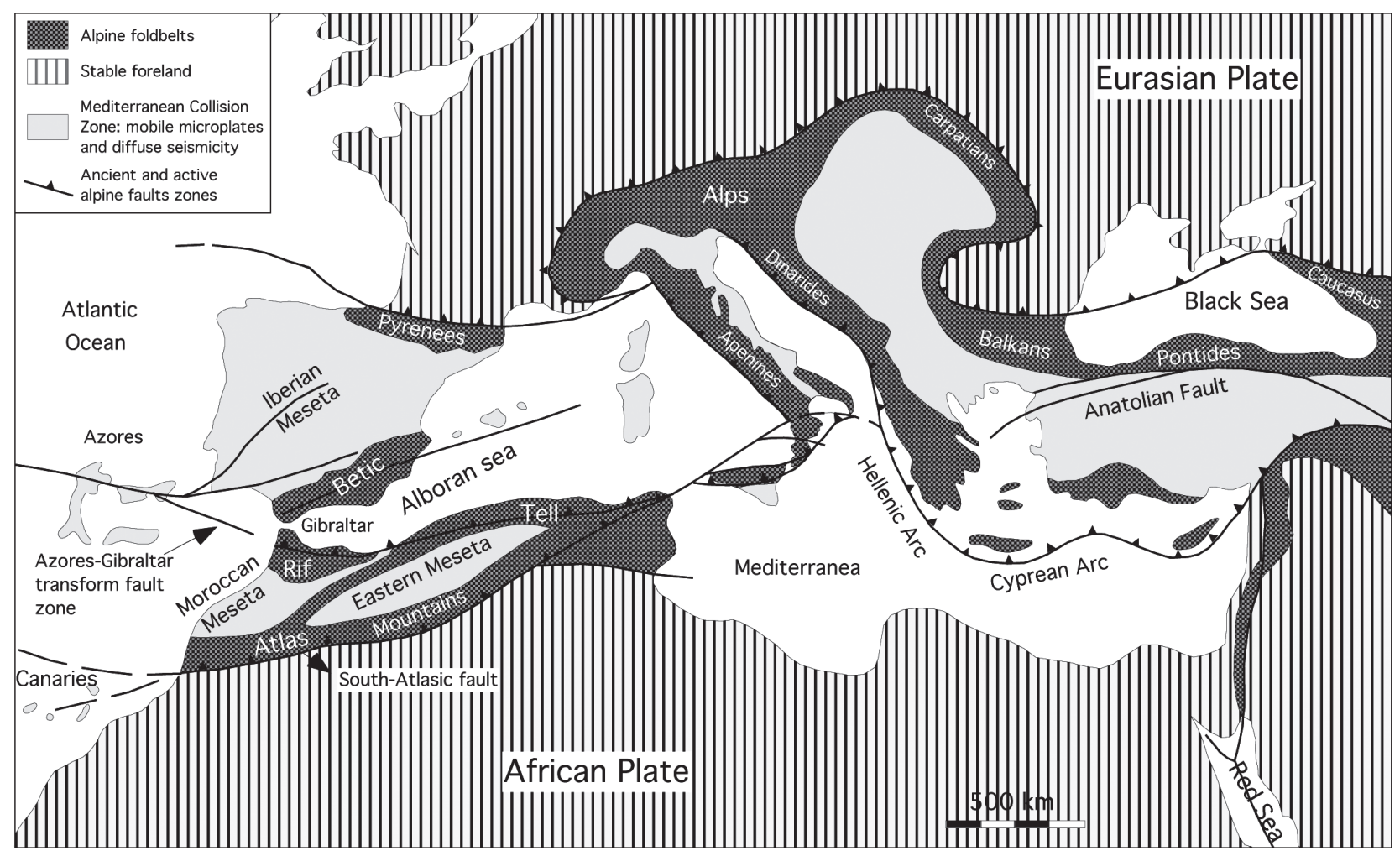

Fig. 5.-Tectonic map of the seismic Mediterranean Collision Zone (MCZ) between the African and Eurasian plates (modified and adapted from Weijermars, 1987). The northern boundary of this zone is outlined by the Pyrenees, Alps, Carpats, Balkan Chain and Caucasus. The former southern boundary of this zone coincides approximately with Hellenic-Cyprean subduction Arcs and the Azores-Gibraltar transform fault zone. We propose in this paper to define the South-Atlasic fault lineament (geosuture) as the present southern boundary of the MCZ (northwestern boundary of the African Plate) than the Azores-Gibraltar fault currently used. This new limit explains clearly the still nowadays seismicity and the widely scattered distribution of earthquake foci localized to the North of the High Atlas lineament (Western Mediterranean Collision Zone).

continental collision. The northern boundary of this zone is outlined by the Pyrenees, Alps, Carpats, Balkan Chain and Caucasus (fig. 5). The southern boundary coincides approximately with HellenicCyprean subduction Arcs and the Azores-Gibraltar transform fault zone.

In spite of the Azores-Gibraltar seismicity clearly outlines the Eurasian-African plate boundary, a diffuse and scattered distribution of earthquake foci is recognized beyond this southern limit until the borders of the High Atlas chain (Thio et al., 1999, Buforn et al., 2004). Seismicity in this region is associated with the plate boundary and may be correlated with the main geological structures present in the area. Consequently, we propose to extend the southern limit of the MCZ to the South-Atlasic fault (subduction feature) lineament than the AzoresGibraltar fault currently used (fig. 5). Plate kinematic models for the region have estimated convergence rates from $4 \mathrm{~mm} / \mathrm{yr}$ at the West to $7.6 \mathrm{~mm} / \mathrm{yr}$ in the
East along the western plate boundary between Eurasia and Africa (Buforn et al., 2004; Argus et al., 1989). The MCZ is also characterised by the mobility of the rigid and involved blocks (Moroccan Meseta, Eastern Meseta, Iberian Meseta...) which is responsible for recent deformation and uplifting of the Atlas Mountains and the Pyrenees. Furthermore, as indicated by field evidence (Morel et al., 1993; 2000) and still nowadays seismicity (Argus et al., 1989; Cherkaoui, 1991; Medina and Cherkaoui, 1991; Buforn et al., 1995; Sébrier et al., 2006), convergence and deformation in the Atlas system of Morocco continue until present times.

\section{Conclusions}

Another interpretation of the geological data is therefore presented here. The vertical jump in the depth of the Moho across the High Atlas, reported 
by Wigger et al. (1992), coupled with the occurrence of the subcrustal velocity inversion (LVZ), observed at $45-50 \mathrm{~km}$ depth, can be interpreted as a beginning of a partial continental subduction feature (crustal imbrication or a Moho duplication). The dip of the fossil plate which could explain the abrupt displacement of the Moho would be northward and agree with the subduction directions beneath the Pyrenees and Alps. The continental collision of Iberia and Europe produced the formation of the Pyrenean orogen with a partial subduction of the Iberian lithosphere to the north (Muñoz, 1992; Roure and Choukroune, 1998; Beaumont et al., 2000). This possibility was confirmed by the magnetotelluric survey along the ECORS profile (Vacher and Souriau, 2001). These studies shows a steep north-dipping, high conductivity body, which reaches a depth of about $70 \mathrm{~km}$ and has been interpreted as subducted partly melted lower crust and lithospheric mantle.

Allowing from the complex problem of the plate boundary in the western zone of the Mediterranean, we propose to interpret the "SAF" zone as the actual northwestern boundary of the stable part of the African plate as proposed by Dewey et al. (1973) and Weijermars (1987). However, the importance of a purely strike-slip component evoked by the latter workers and by Mattauer et al. (1977) to explain the Alpine structuring of the High Atlas is not supported by recent fault kinematic results (Jacobshagen, 1992; Errarhaoui, 1998; Beauchamp et al., 1999; El Harfi 2001; El Harfi et al., 2001).

The problem of the significance of the "SAF" zone is thus currently posed in this way: Strike-slip faultings or overthrustings?. Either it is a succession of strike-slip faults of variable orientation and displacement, or it could be a set of thin-skin overthrusts directed towards the south. It is not certain whether these two interpretations are mutually exclusive, since the South-Atlasic boundary can react differently from one section to another as a function of the pre-existing segmentation. In any case, additional studies and reflection seismic surveys remain necessary in this area to highlight and clarify the deep structure of the High Atlas and to specify the trajectory and the prolongation of the "SAF".

Unfortunately, research groups studying active faults and seismicity in the Western Mediterranean do not include the High Atlas in their programmes. Nevertheless, better knowledge of the crustal structure in the Atlas system of Morocco is important not only for solving the complex nature of the plate boundary between Africa and Eurasia but also to increase the accuracy of predicting earthquakes that might put Mediterranean people, particularly in Spain, France, Portugal, Morocco, Algeria and Tunisia, at risk.

\section{ACKNOWLEDGEMENTS}

This study and the works in the field have greatly benefited from cooperation programmes between Dijon (France)-Marrakech-Agadir (Morocco) universities. We would like to acknowledge the ONAREP "Moroccan National Office of Research and Petroleum Exploration" for their assistance. We are much obliged to Prof. Pierre Tricart (University of Grenoble, France) and an other reviewer who improved the manuscript by a careful review.

\section{References}

Afrique, P. N. (2002). Anomalie de Bouguer, Afrique du Nord. Total Fina Elf, scale 1:4.000.000, 1 sheet, confidential.

Argus, D. F., Gordon, R.G., De Mets, C. \& Stein, S. (1989). Closure of Africa-Eurasia-North America plate motion circuit and tectonics of the Gloria fault. J. Geophys. Res., 94: 5585-5602.

Ayarza, P., Álvarez-Lobato, F., Teixell, A., Arboleya, M. L., Tesón, E., Julivert, M. \& Charroud, M. (2005). Crustal structure under the central High Atlas Mountains (Morocco) from geological and gravity data. Tectonophysics, 400: 67-84.

Beauchamp, W., Barazangi, M., Demnati, A. \& El Alji, M. (1996). Intracontinental rifting and inversion: The Missour bassin and Atlas Mountains of Morocco. A.A.P.G. Bulletin, 80: 1459-1482.

Beauchamp, W., Allmendinger, R. W., Barazangi, M., Demnati, A. \& Dahmani, M. (1999). Inversion tectonics and evolution of the High Atlas Mountains, Morocco, based on a geological-geophysical transect. Tectonics, 18: 163-185.

Beaumont, C., Muñoz, J. A., Hamilton, J. \& Fullsack, P. (2000). Factors controlling the Alpine evolution of the central Pyrenees inferred from a comparison of observations and geodynamical models. J. Geophys. Res., 105: 8121-8145.

Bernini, M., Boccaletti, M., Moratti, G. \& Papani, G. (2000). Structural developement of the Taza-Guercif Basin as a constraint for the Middle Atlas Shear Zone tectonic evolution. Mar. Petrol. Geol., 17: 391-408.

Berrahma, M. \& Delaloye, M. (1989). Données géochronologiques nouvelles sur le massif volcanique du Siroua (Haut-Atlas, Maroc). J. Afr. Earth Sci., 9: 651-656.

Buforn, E., Sanz de Galdeano, C. \& Udias, A. (1995). Seismotectonics of the Ibero-Maghrebian region. Tectonophysics, 228: 247-261. 
Buforn, E., Bezzeghoud, M., Udias, A. \& Pro, C. (2004). Seismic Sources on the Iberia-African Plate Boundary and their Tectonic Implications. Pure Appl. Geophys., 161: 623-646.

Cherkaoui, T. E. (1991). Contribution à l'étude de l'aléa sismique au Maroc. Ph.D. Thesis, Université de Grenoble, 246 p.

Chorowicz, J., Emran, A. \& Alem, E. M. (2001). Tectonique et venues volcaniques en contexte de collision, exemple du massif néogène du Siroua (Atlas Marocain): effets combinés d'une transformante et de la suture panafricaine. Can. J. Earth Sci., 38: 411-425.

Dewey, J., Pitman, W. C., Ryan, W. B. F. \& Bonnin, J. (1973). Plate tectonics and the evolution of the Alpine system. Geol. Soc. Amer. Bull., 84: 3137-3180.

Dewey, J. F., Helman, M. L., Turco, E., Hutton, D. W. H. \& Knott, S. D. (1989). Kinematics of the western Mediterranean. In: Alpine tectonics (M. P. Coward, D. Dietrich and R. G. Park, ed.) Geol. Soc. London Special Pub., 45: 265-284.

El Harfi, A. (2001) Tectonic and sedimentary evolution of the South-Atlasic front (Central and Eastern High Atlas Mountains, Morocco) during Cenozoic times, Ouarzazate foreland basin. Ph.D. Thesis, Univ. Marrakech, $366 \mathrm{p}$.

El Harfi, A., Lang, J., Salomon, J. \& Chellai, E. H. (2001). Cenozoic Sedimentary dynamics of the Ouarzazate Foreland Basin (Central High Atlas Mountains, Morocco). Int. J. Earth Sci. (Geol. Rundsch.), 90: 393-411.

El Harfi, A., Guiraud, M. \& Lang, J. (2006). Deep-rooted "thick skinned" model for the High Atlas Mountains (Morocco). Implications for the structural inheritance of the southern Tethys passive margin. J. Structural Geol., 28: 1958-1976. doi : 10.1016/j.jsg.2006.08.011.

Ennih, N. \& Liégeois, J. P. (2001). The Moroccan AntiAtlas: the West African craton passive margin with limited Pan-African activity. Implications for the northern limit of the craton. Precambrian Res., 112: 289-302.

Errarhaoui, K. (1998). Structure du Haut-Atlas: plis et chevauchements du socle et de couverture, interprétations des données géophysiques et géologiques. Ph.D. Thesis, Univ. Paris, 328 p.

Giese, P. \& Jacobshagen, V. H. (1992). Inversion tectonics of intracontinental ranges: High and Middle Atlas, Morocco. Geol. Rundsch., 81: 249-259.

Gomez, F., Allmendinger, R. W., Barazangi, M., Er Raji, A. \& Dahmani, M. (1998). Crustal shortening and vertical strain partitioning in the Middle Atlas Mountains of Morocco. Tectonics, 17: 520-533.

Gomez, F., Beauchamp, W. \& Barazangi, M. (2000). Role of the Atlas Mountains (northwest Africa) within the African-Eurasian plate-boundary zone. Geology, 28: 775-778.

Harmand, C. \& Cantagrel, J. M. (1984). Le volcanisme alcalin Tertiaire et Quaternaire du Maroc: chronologie K-Ar et cadre géodynamique. J. Afr. Earth Sci., 2: 51-55.

Hatzfeld, D. \& Frogneux, M. (1981). Intermediate depth seismicity in the western Mediterranean unre- lated to subduction of oceanic lithosphere. Nature, 292: 443-445.

Ibhi, A. (2000). Le volcanisme Plio-quaternaire de Saghro (Haut-Atlas central, Maroc) et les enclaves basiques et ultrabasiques associées. Ph.D. Thesis, Univ. Agadir, 359 p.

Jacobshagen, V. (1992). Major fracture zones of Morocco: The South Atlas and the Transalboran fault systems. Geol. Rundsch., 81: 185-197.

Laville, E. (1985). Évolution sédimentaire, tectonique et magmatique du bassin jurassique du Haut-Atlas (Maroc): modèle en relais multiples de décrochements. $\mathrm{PhD}$ Thesis, Univ. Montpellier, $166 \mathrm{p}$.

Laville, E. \& Piqué, A. (1991). La distension crustale atlantique et atlasique au Maroc au début du Mésozoïque: le rejeu des structures hercyniennes. Bull. Soc. Géol. France, 162: 1161-1171.

Makris, J., Demnati, A. \& Klussmann, J. (1985). Deep seismic soundings in Morocco and a crust and upper mantle model deduced from seismic and gravity data. Ann. Geophysicae, 3: 369-380.

Marone, F., Van Der Meijde, M., Van Der Lee, S. \& Giardini, D. (2003). Joint inversion of local, regional and teleseismic data for crustal thickness in the EurasiaAfrica plate boundary. Geophys. J. Int., 154: 499-514.

Mattauer, M., Tapponier, P. \& Proust, F. (1977). Sur les mécanismes de formation des chaînes intracontinentales. L'exemple des chaînes atlasiques du Maroc. Bull. Soc. géol. France, 7: 521-552.

Medina, F. \& Cherkaoui, T. (1991). Focal mechanisms of the Atlas earthquakes, and tectonic implications. Geol. Rundsch., 80: 639-648.

Michard, A., Chalouan, A., Feinberg, H. \& Goffe, B., (2002). Montigny, R. How does the Alpine belt end between Spain and Morocco? Bull. Soc. Géol. France, 173: 3-15.

Morel, J. L., Zouine, E. M. \& Poisson, A. (1993). Relation entre la subsidence des bassins moulouyens et la création des reliefs atlasiques (Maroc): un exemple d'inversion tectonique depuis le Néogène. Bull. Soc. Géol. France, 164: 79-91.

Morel, J. L., Zouine, E. M., Andrieux, J. \& FaureMuret, A. (2000). Déformations néogènes et quaternaires de la bordure nord haut atlasique (Maroc): rôle du socle et conséquences structurales. J. Afr. Earth Sci., 30: 119-131.

Munoz, J. A. (1992). Evolution of a continental collision belt: ECORS-Pyrenees crustal balanced crosssection. In: Thrust Tectonics (K.R. McClay), New York, 235-246.

Piqué, A. \& Michard, A. (1989). Moroccan Hercynides: a synopsis. The Paleozoic sedimentary and tectonic evolution at the northern margin of West Africa. Amer. J. Sci., 289: 286-330.

Piqué, A., Dahmani, M., Jeannette, D. \& Bahi, L. (1987). Permanence of structural lines in Morocco from Precambrian to present. J. Afr. Earth Sci., 6: 247-256.

Piqué, A., Aït Ouali, R., Amrhar, M., Charroud, M., Gourmelen, C., Laville, E., Rekhiss, F. \& Tricart, P. 
(1998). Évolution structurale des domaines atlasiques du Maghreb au Méso-Cénozoïque; le rôle des structures héritées dans la déformation du domaine atlasique de l'Afrique du Nord. Bull. Soc. Géol. France, 169: 797-810.

Piqué, A., Tricart, P., Guiraud, R., Laville, E., Bouaziz, S., Amrhar, M. \& Ait Ouali, R. (2002). The MesosoicCenozoic Atlas belt (North Africa): an overview. Geodin. Acta, 15: 185-208.

Qureshi, S. N. (1986). Crustal studies of Morocco from gravity and seismic data. Dissertation, Fachbereich Geowissenschaften, Univ Hamburg., 120 p.

Rod, E. (1962). Fault pattern, northwest corner of Sahara Shield. A.A.P.G. Bull., 46: 529-552.

Roure, F. \& Choukroune, P. (1998). Contribution of the Ecors seismic data to the Pyrenean geology: crustal architecture and geodynamic evolution of the Pyrenees. Mém. Soc. Géol. France, 173: 37-52.

Russo, P. \& Russo, L. (1934). Le grand accident sudatlasien. Bull. Soc. Géol. France, 4: 375-384.

Sandvol, E., Calvert, A. \& Barazangui, M. (1998). Grid search modelling of receiver functions: implications for crustal structure in the Middle East and North Africa. J. Geophys. Res., 103: 26899-26917.

Schwarz, G., Mehl, H. G., Ramdani, F. \& Rath, V. (1992). Electrical resistivity structure of the eastern Moroccan Atlas System and its Tectonic implications. Geol. Rundsch., 81: 221-235.

Seber, D., Barazangi, M., Ibenbrahim, A. \& Demnati, A. (1996). Geophysical evidence for lithospheric delamination beneath the Alboran Sea and Rif-Betic mountains. Nature, 379: 785-790.

Sébrier, M., Siame, L., Zouine, M., Winter, T., Missenard, Y. \& Leturmy, P. (2006). Active tectonics in the Moroccan High Atlas. C. R. Geoscience, 338: 65-79.

Souriau, A. \& Granet, M. (1995). A tomographic study of the lithosphere beneath the Pyrenees from local and teleseismic data. J. Geophys. Res., 100: 18117-18134.
Tadili, B., Ramdani, M., Ben Sari, D., Chapochnikov, K. \& Bellot, A. (1986). Structure de la croûte dans le Nord du Maroc. Ann. Geophysicae, 4: 99-104.

Thio, H. K., Song, X., Saikia, C. K., Helmberger, D. V. \& Woods, B. B. (1999). Seismic source and structure estimation in the western Mediterranean using a sparse broadband network. J. Geophys. Res., 104: 845-861.

Vacher, P. \& Souriau, A. (2001). A 3D model of the Pyrenean deep structure based on gravity modelling, seismic images and petrological constraints. Geophys. J. Int., 145: 460-470.

Van Den Bosch, J. W. H. (1971). Carte gravimétrique du Maroc au 1/500.000, Anomalie de Bouguer d = 2,67. Notes Mém. Serv. Géol. Maroc 21, 234 p.

Van der Meijde, M., Van der Lee, S. \& Giardini, D. (2003). Crustal structure beneath broad-band seismic stations in the Mediterranean region. Geophys. Jour. Int., 152: 729-739.

Vergés, J., Fernández, M. \& Martínez, A. (2002). The Pyrenean orogen: pre- syn- and post-collisional evolution. In: Reconstruction of the evolution of the AlpineHimalayan Orogen (G. Rosenbaum and G. S. Lister, ed.) J. Virt. Explorer, 8: 57-76.

Weijermars, R. (1987). A revision of the EurasianAfrican plate boundary in the western Mediterranean. Geol. Rundsch., 76: 667-676.

Wigger, P., Asch, G., Giese, P., Heinsohn, W. D., El Alami, S. O. \& Ramdani, F. (1992). Crustal structure along a traverse across the Middle and High Atlas Mountains derived from seismic refraction studies. Geol. Rundsch., 81: 237-248.

Zeyen, H., Ayarza, P., Fernández, M. \& Rimi, A. (2005). Lithospheric structure under the western African-European plate boundary: a transect across the Atlas Mountains and the Gulf of Cadiz. Tectonics, 24: TC2001, doi:10.1029/2004TC001639.

Recibido el 8 de junio de 2005 Aceptado el 28 de junio de 2007 